\title{
Ingestion and aspiration of foreign bodies in dental practice
}

\section{Połknięcia i aspiracje ciał obcych w praktyce stomatologicznej}

\section{Kamila Martyna Wróbel-Bednarz ${ }^{1}$, Andrzej Wróbel ${ }^{2}$, Daniel Surowiecki ${ }^{3}$, Agata Walczyk ${ }^{3}$}

\author{
${ }^{1}$ Katedra Protetyki Stomatologicznej, Warszawski Uniwersytet Medyczny \\ Department of Prosthodontics, Medical University of Warsaw \\ Head: prof. dr hab. n. med. Elżbieta Mierzwińska-Nastalska \\ ${ }^{2}$ Pracownia Endoskopii, Szpital Powiatowy w Mińsku Mazowieckim \\ Endoscopy Diagnostic Lab, Regional Hospital in Minsk Mazowiecki \\ ${ }^{3}$ Studenckie Koło Naukowe przy Katedrze Protetyki Stomatologicznej, Warszawski Uniwersytet Medyczny \\ Students' Research Group at the Department of Prosthodontics, Medical University of Warsaw
}

KEY WORDS:

ingestion, aspiration, foreign body, denture

\section{Summary}

Dental work requires the use of various types of materials and tools. Due to the lack of a complete mechanical barrier that would protect further parts of the respiratory and digestive systems, aspirations and ingestions are seen as complications. It is then appropriate to establish proper protocols, diagnostics and treatment methods to be performed both at the chairside and in specialist departments. According to the literature, drill bits, endodontic tools and prosthetic restorations, especially at the stage of oral cavity control before cementation, are predisposed to enter the alimentary or respiratory tract. Most swallowed objects pass through the digestive tract without any alarming complications. However, sharp, pointed and elongated objects can cause perforation and damage to internal organs. The patient's behavior, vital parameters and other clinical manifestations should be carefully monitored, which could help in the differentiation between accidental ingestion and aspiration. However medical intervention may be necessary in both situations. After
HASŁA INDEKSOWE:

połknięcia, aspiracja, ciało obce, proteza

\section{Streszczenie}

Charakterystyka pracy lekarza dentysty wymaga stosowania różnego rodzaju materiałów $i$ narzędzi w jamie ustnej pacjenta. Z uwagi na brak calkowitej, mechanicznej bariery chroniacej dalsze odcinki układów oddechowego i pokarmowego, mogacymi zdarzyć się powiktaniami zabiegów stomatologicznych sq aspiracje i potknięcia. Celowym jest ustalenie wtaściwego toku postępowania, diagnostyki i leczenia $w$ takich sytuacjach zarówno na fotelu stomatologicznym, jak $i$ w oddziałach specjalistycznych. Na podstawie opisywanych $w$ piśmiennictwie przypadków można stwierdzić, że szczególnie predysponowane do przedostania się do drogi pokarmowej lub oddechowej sa wiertta, narzędzia endodontyczne, uzupetnienia protetyczne, zwłaszcza na etapie kontroli w jamie ustnej przed zacementowaniem. Większość polkniętych przedmiotów transportowana jest przez przewód pokarmowy bez żadnych alarmujacych dolegliwości. Jednak ostre, spiczaste $i$ wydlużone przedmioty moga spowodować perforację $i$ uszkodzenia narzadów wewnętrznych. Należy bacznie obserwować zachowanie 
the diagnostic procedure, $15-20 \%$ of cases of swallowing of a foreign body require intervention in the form of endoscopic or surgical removal. The optimal therapeutic management of a patient who has been diagnosed with foreign body aspiration involves bronchoscopy with a rigid device. The basis for preventing the occurrence of the described complications is the mechanical protection of the respiratory and digestive tracts. The most common method used in dentistry is the use of a rubber dam. If its application is not possible, the operator should take special care with any moveable object present in the mouth. In the case of failure, the patient's condition should be monitored and methods that go beyond the competence of the dentist, including surgical treatment, should be implemented.

\section{Introduction}

Dental work requires the use of various types of materials and tools in the patient's mouth. Due to the lack of a complete mechanical barrier that protects further parts of the respiratory and digestive systems, aspirations and ingestions are common complications of dental procedures. Numerous publications describing such cases can be found in the literature, so it is advisable to determine the proper course of action, diagnosis and treatment in such situations, both in the dental chair and in specialist departments. It is also important to assess the probability of this type of complications occurring in specific clinical situations to implement appropriate pacjenta, jego parametry życiowe $i$ inne objawy kliniczne, które moga pomóc $w$ różnicowaniu między przypadkowym polknięciem a aspiracja. $W$ obu sytuacjach niezbędna może okazać się interwencja medyczna. Po przeprowadzonym postepowaniu diagnostycznym, w 15-20\% przypadków połknięcia ciała obcego niezbędna jest interwencja w postaci usunięcia endoskopowego lub chirurgicznego. Postepowanie z pacjentem, $u$ którego rozpoznano aspiracje ciała obcego obejmuje bronchoskopię aparatem sztywnym. Podstawa $w$ zapobieganiu wystepowania opisywanych powiktań jest mechaniczne zabezpieczenie dróg oddechowych i pokarmowych. Najbardziej rozpowszechniona metoda w stomatologii jest użycie koferdamu. W wielu sytuacjach zastosowanie opisanych barier nie zawsze jest możliwe. Wówczas operator powinien zachować szczególna ostrożność z każdym potencjalnie ruchomym elementem znajdujacym się w jamie ustnej. W przypadku niepowodzenia należy monitorować stan pacjenta i sięgać po metody wykraczajace poza kompetencje lekarza dentysty, obejmujace leczenie chirurgiczne.

\section{Wprowadzenie}

Charakterystyka pracy lekarza dentysty wymaga stosowania różnego rodzaju materiałów i narzędzi w jamie ustnej pacjenta. $Z$ uwagi na brak całkowitej, mechanicznej bariery chroniącej dalsze odcinki układu oddechowego i pokarmowego, mogą mieć miejsce powikłania zabiegów stomatologicznych w postaci aspiracje i połknięcia. W piśmiennictwie można odnaleźć publikacje opisujące takie przypadki, dlatego celowym jest ustalenie właściwego toku postępowania, diagnostyki i leczenia w takich sytuacjach zarówno na fotelu stomatologicznym, jak i w oddziałach specjalistycznych. Ważna jest również gradacja prawdopodobieństwa 
preventive safety measures. This paper systematizes knowledge about the occurrence of the discussed complications, the diagnostic and clinical procedure and proposes a series of activities aimed at preventing aspiration or ingestion.

\section{Occurrence of aspirations and ingestions in dental practice}

Each dental specialty is characterized by the use of specific materials and tools in small dimensions used by the dentist. Based on the cases described in the literature it can be stated that especially predisposed to enter the alimentary or respiratory tract are drills used in conservative dentistry and prosthetics, endodontic tools, including finger files and rotary tips, prosthetic restorations, especially at the oral cavity control stage before cementation, and even implant screwdrivers. ${ }^{1-5}$ When orthodontic braces are worn, brackets, clasps and much larger objects, such as wire fragments, can be ingested. ${ }^{6}$ Also during impression taking, aspiration or ingestion of the impression material may occur, as well as during procedures when acrylic, composite or any other material is introduced into the mouth of the patient, especially in a liquid consistency. The risk of this type of complications is more frequent than in the past, due to the greater tendency of dentists to work with the patient in the supine position. It is undoubtedly more ergonomic and presents a number of advantages, however, in the described context, it becomes a risk factor for the discussed complications. ${ }^{7}$ Patients who are particularly vulnerable to aspiration or ingestion are children from 1 to 3 years of age, as well as the elderly, the intoxicated, the mentally retarded, and those with a reduced respiratory defense mechanism and impaired gag reflex. ${ }^{8}$ According Susini et al., a vast majority of complications include ingestions, which improves the prognosis, especially in the case of rounded and blunt wystąpienia tego typu powikłań w konkretnych sytuacjach klinicznych, aby wdrażać odpowiednie prewencyjne środki bezpieczeństwa w celu ich zapobieżenia. W niniejszej pracy usystematyzowano wiedzę dotyczącą występowania omawianych powikłań, sposobu postępowania diagnostycznego oraz klinicznego jak również przedstawiono szereg czynności, których celem jest niedopuszczenie do aspiracji lub połknięcia.

Występowanie aspiracji i połknięć w praktyce stomatologicznej

Poszczególne specjalności stomatologiczne charakteryzują się użyciem specyficznych narzędzi i materiałów w niewielkich wymiarach, którymi posługuje się lekarz. Na podstawie opisywanych $\mathrm{w}$ piśmiennictwie przypadków można stwierdzić, że szczególnie predysponowane do przedostania się do drogi pokarmowej lub oddechowej są używane w stomatologii zachowawczej i protetyce wiertła, narzędzia endodontyczne, w tym pilniki palcowe oraz końcówki obrotowe, uzupełnienia protetyczne, zwłaszcza na etapie kontroli w jamie ustnej przed zacementowaniem, a nawet śrubokręty implantologiczne. ${ }^{1-5} \mathrm{~W}$ trakcie użytkowania aparatów ortodontycznych może dojść do połknięcia zamków, klamer, a także znacznie większych obiektów, jak fragmenty drutu. ${ }^{6}$ Również podczas pobierania wycisków może dojść do aspiracji lub połknięcia masy wyciskowej, podobnie jak podczas pracy z użyciem akrylu, kompozytu, czy jakimkolwiek innym materiałem wprowadzanym do jamy ustnej pacjenta, szczególnie w konsystencji półpłynnej. ${ }^{7}$ Ryzyko tego typu powikłań staje się częstsze niż w przeszłości, ze względu na większą skłonność lekarzy do pracy z pacjentem leżącym. Jest to niewątpliwie bardziej ergonomiczna i posiadająca szereg zalet pozycja, jednak w opisywanym kontekście staje się czynnikiem ryzyka omawianych powikłań. ${ }^{7}$ Pacjenci szczególnie narażeni na aspirację lub połknięcie to 
objects. The authors of that study point to the lack of use of rubber dam during endodontic treatment as the main risk factor of this type of complications. ${ }^{9}$ Particularly dangerous are aspirations, which often lead to further hospital treatment, as well as swallowing sharp objects that may damage individual sections of the gastrointestinal tract. ${ }^{1,10}$ The ingestion of large object, whose passage through the entire digestive tract is impossible, also requires urgent intervention. ${ }^{11,12}$

It should beremembered that the complications described above may not occur only during a visit to the dentist's office, but also at any time, even after many years from the occurrence of such a situation like ingestion by the patient. Debonding of prosthetic restorations, including posts is the most frequently reported complication that the patient potentially should be informed about. ${ }^{13,14}$ Special care should be given to patients suffering from epilepsy. According to the studies performed by Gawlak et al. such patients are exposed, among others, to damage to teeth or oral restorations during epileptic seizures, and so this group of patients require special treatment and protection against accidental entry of these objects into the airways or alimentary tract. ${ }^{15,16}$

\section{Diagnostics}

Ingestions and aspirations of foreign bodies are a frequent and potentially dangerous complication that poses a risk of severe or life threatening complications. The symptoms mostly depend on the size and shape of the foreign body, as well as the place where it became obstructed. Most swallowed objects pass through the digestive tract without any alarming ailments. ${ }^{10}$ Usually the swallowed instruments pass through the gastrointestinal tract asymptomatically and atraumatically within 2 days to 4 weeks. 3 However, sharp, pointed and elongated objects, for example reamers and endodontic files, can cause dzieci w wieku od 1 do 3 lat, osoby w podeszłym wieku, nietrzeźwe, upośledzone umysłowo, ze zmniejszonym mechanizmem obronnym dróg oddechowym oraz z upośledzonym odruchem wymiotnym. ${ }^{8}$ Zgodnie $\mathrm{z}$ badaniami Susini i wsp. w zdecydowanej większości dochodzi do połknięcia przedmiotu, co poprawia rokowanie, zwłaszcza w przypadku przedmiotów obłych i tępych. Autorzy przytoczonego badania wskazują na brak stosowania koferdamu podczas leczenia endodontycznego, jako głównego czynnika ryzyka tego typu powikłań. ${ }^{9}$ Szczególnie groźne są aspiracje, które często prowadzą do dalszego leczenia szpitalnego, a także połknięcia ostrych przedmiotów, mogących uszkadzać poszczególne odcinki przewodu pokarmowego. ${ }^{1,10}$ Pilnej interwencji wymaga również połknięcie dużego przedmiotu, którego pasaż przez cały przewód pokarmowy jest niemożliwy. ${ }^{11,12}$

Należy pamiętać, że opisywane komplikacje nie występują jedynie podczas wizyty w gabinecie dentystycznym, ale także w dowolnym czasie, nawet po wielu latach od zaistnienia takiej sytuacji połknięcia ciała obcego przez pacjenta. Odcementowanie uzupełnień protetycznych, m.in. wkładów koronowo-korzeniowych jest najczęściej opisywanym powikłaniem, o którym pacjent powinien zostać poinformowany. ${ }^{13,14}$ Specjalną troską powinni zostać objęci pacjenci cierpiący na padaczkę. Zgodnie z badaniami Gawlak i wsp. są oni narażeni m.in. na uszkodzenie zębów, czy obecnych w jamie ustnej uzupełnień protetycznych w trakcie napadów padaczkowych, co sprawia, że ta grupa pacjentów wymaga szczególnego traktowania i zabezpieczenia przed przypadkowym przedostaniem się wspomnianych przedmiotów do dróg oddechowych lub pokarmowej. ${ }^{15,16}$

\section{Diagnostyka}

Połknięcia i aspiracje ciał obcych są potencjalne groźnym powikłaniem niosącym ryzyko zagrożenia życia lub ciężkich komplikacji. 
perforation and damage to internal organs. ${ }^{17}$ About $60 \%$ of the objects are trapped at the level of the oral part of the throat. The patient may then inform about a clear feeling of the presence of a foreign body in the throat, increased salivation, gag reflex, difficulty and pain while swallowing. ${ }^{9}$ Other symptoms of ingestion include dysphagia, retrosternal pain, sore throat and vomiting with food content. If the object is quite large and visible through the mouth, it can be carefully removed with the help of forceps or fingers, taking care not to push it into the deeper part of the digestive tract. $^{2,18}$ If the object or its component can not be recovered, it is necessary to stop the procedure, remove the rubber dam and other objects from the oral cavity. The patient's behaviour, vital parameters and other clinical symptoms should be carefully monitored. It could help in the differentiation between accidental ingestion and aspiration. However, medical intervention may be necessary in both situations. ${ }^{19}$ If the foreign body cannot be removed at the dentist's office, the patient should be informed about possible complications and escorted to the hospital in order to determine the location of the object and make a decision on further procedure and required treatment.

Prelimininary assessment of the patient consists in anteroposterior, lateral chest and abdomen radiographs. The lateral radiographs make it easier to recognize not well visible foreign objects. In the case of aspirated foreign bodies, radiographs during inhalation and exhalation are useful and in a lying position. Next, pictures of soft neck tissues make it easier to detect objects in the upper respiratory tract. ${ }^{20}$ The aspirated object usually enters the right bronchial tree because it is wider and more upright. Its removal requires surgical intervention. $^{2}$ Endoscopic examination (Fig. 2) is indicated in situations when sharp and oblong items have been swallowed due to the high risk (up to $35 \%$ ) of perforation of the
Objawy zależą w dużej mierze od rozmiaru i kształtu ciała obcego, a także miejsca w którym zostało ono zatrzymane. Większość połkniętych przedmiotów przechodzi przez przewód pokarmowy bez żadnych alarmujących dolegliwości. ${ }^{10}$ Zwykle połknięte instrumenty przemieszczają się przez przewód pokarmowy bezobjawowo i atraumatycznie w ciągu 2 dni do 4 tygodni. ${ }^{3}$ Jednak ostre, spiczaste i wydłużone przedmioty, takie jak poszerzacze i pilniki endodontyczne mogą spowodować perforację i uszkodzenia narządów wewnętrznych. ${ }^{17}$ Około 60\% przedmiotów zostaje uwięzionych na poziomie części ustnej gardła. Pacjent może informować wtedy o wyraźnym uczuciu obecności ciała obcego w gardle, może pojawić się wzmożone ślinienie, odruch wymiotny, trudności i ból podczas przełykania. ${ }^{9}$ Do innych objawów połknięcia zalicza się dysfagię, ból zamostkowy, ból gardła oraz wymioty treścią pokarmową. Jeżeli przedmiot jest dość duży i widoczny poprzez jamę ustną, można go ostrożnie wyjąć za pomocą kleszczy lub palców, uważając przy tym, aby nie popchnąć go W głębszą część przewodu pokarmowego. ${ }^{2,18}$ Jeżeli przedmiot lub jego element nie może zostać odzyskany, konieczne jest zaprzestanie procedur, wyjęcie koferdamu i pozostałych przedmiotów z jamy ustnej. Należy bacznie obserwować zachowanie pacjenta, jego parametry życiowe i inne objawy kliniczne, które mogą pomóc $\mathrm{w}$ różnicowaniu między przypadkowym połknięciem a aspiracją. W obu sytuacjach niezbędna może okazać się interwencja medyczna. ${ }^{19}$ Przy braku możliwości usunięcia ciała obcego w gabinecie stomatologicznym, pacjent powinien zostać poinformowany o możliwych komplikacjach i eskortowany do szpitala w celu określenia położenia obiektu i podjęcia decyzji co do dalszego postępowania i wymaganego leczenia.

Wstępna ocena pacjenta polega na wykonaniu radiologicznych zdjęć przeglądowych jamy brzusznej oraz klatki piersiowej w projekcji 


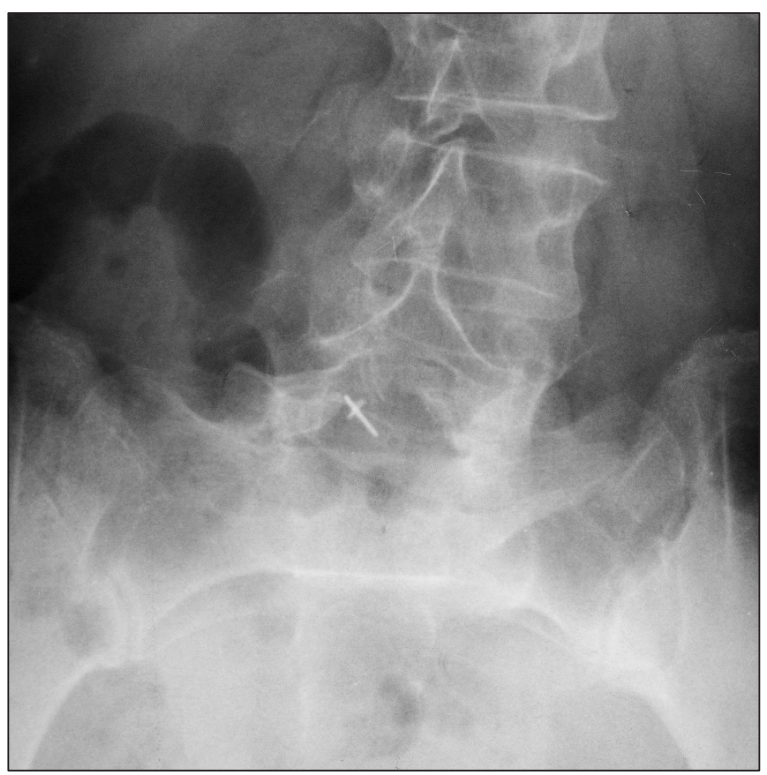

Fig. $1 \mathrm{X}$-ray of the abdomen - swallowed post and core is visible.

Ryc. 1. Zdjęcie RTG jamy brzusznej - widoczny potknięty wktad koronowo-korzeniowy.

gastrointestinal tract. 2,20 With an endoscope it is often possible to remove the ingested foreign body. Urgent endoscopy is mandatory in the case of symptoms of airway obstruction or the presence of other signs of serious complications. Some objects, such as acrylic teeth, resin fillings or impression materials, are made of radiolucent substances, making their identification and localization impossible. It is then necessary to perform bronchoscopy, endoscopy or computed tomography. ${ }^{2,21-24} \mathrm{~A}$ negative radiographic examination result never excludes the presence of foreign bodies in the airways or the digestive tract. Therefore, in the presence of symptoms, further diagnostic procedures are always necessary. In the case of aspiration, the clinical manifestation includes the occurrence of acute asphyxia, chronic cough, choking, recurrent upper respiratory tract infections, haemoptysis and pneumonia. Clinical symptoms in such situations may imitate those seen in the case of bronchial asthma. ${ }^{9,25}$ It should be remembered that some

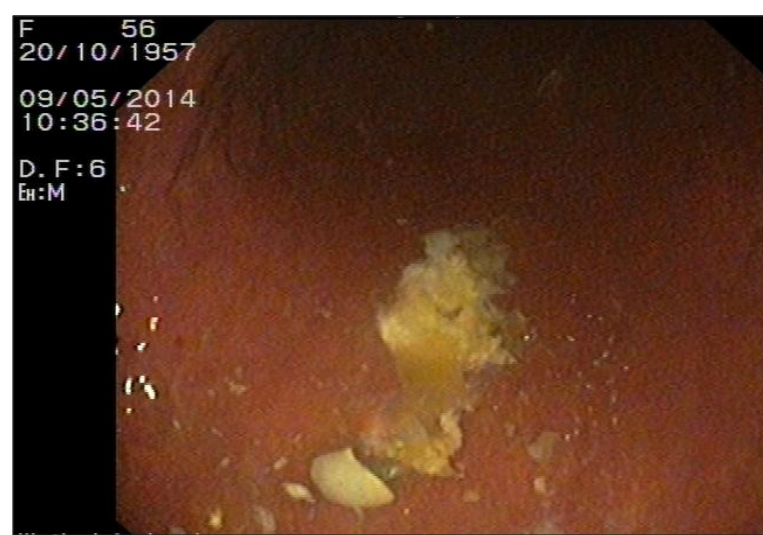

Fig. 2 Gastroscopy picture of a patient who swallowed a prosthetic restoration.

Ryc. 2. Gastroskopia pacjenta, u którego stwierdzono połknięcie uzupetnienia protetycznego.

przednio-tylnej i bocznej (ryc. 1). Zdjęcia boczne ułatwiają rozpoznanie trudno widocznych ciał obcych. W przypadku dostania się ciał obcych do dróg oddechowych przydatne bywają zdjęcia podczas wdechu i wydechu oraz w pozycji leżącej. Zdjęcia tkanek miękkich szyi ułatwiają natomiast wykrycie przedmiotów $\mathrm{w}$ górnych drogach oddechowych. ${ }^{20}$ Zaaspirowany obiekt najczęściej wpada do prawego drzewa oskrzelowego, ponieważ jest ono szersze i ustawione bardziej pionowo. Taka sytuacja wymaga interwencji chirurgicznej w celu jego usunięcia. ${ }^{2}$ Badanie endoskopowe (ryc. 2) wskazane jest w sytuacjach, kiedy połknięte zostały ostre i podłużne przedmioty ze względu na duże ryzyko przedziurawienia ściany przewodu pokarmowego, sięgające nawet 35\%.2,20 Przy pomocy endoskopu często możliwe jest usunięcie połkniętego ciała obcego. Pilna endoskopia jest obowiązkowa w przypadku wystąpienia objawów niedrożności dróg oddechowych lub obecności innych oznak ciężkich powikłań. Niektóre obiekty, takie jak: zęby akrylowe, wypełnienia z żywicy lub masy wyciskowe są wykonane $\mathrm{z}$ materiałów, które przepuszczają promieniowanie rentgenowskie, co uniemożliwia ich identyfikację i zlokalizowanie. Konieczne jest wówczas 
patients are asymptomatic and the radiological and endoscopic diagnostics will play the main role. The radiological symptoms of aspiration include a visible, contrasting, heterogeneous foreign body, emphysema, atelectasis or mediastinal hemorrhage. In the endoscopic examination, granulation tissue, pus secretion, swelling and hardening of the bronchial tree and bleeding can be observed. ${ }^{26,27}$

\section{Ad hoc and specialist treatment}

After the diagnostic procedure, $15-20 \%$ of cases of swallowing a foreign body require intervention in the form of endoscopic or surgical removal. Children from 6 months up to 6 years of age and the elderly ( $7^{\text {th }}$ decade of life) dominate in the group of people who may be affected by this problem. ${ }^{8}$ Indications for urgent intervention are situations when the foreign body becomes stuck in the esophagus or blocked food pieces cause complete dysphagia. Other swallowed foreign objects may include electric batteries that carry the risk of perforation or chemical burns caused by their contents, as well as sharp tips, especially double-ended ones. Planned procedure should be considered in the following situations: a swallowed foreign body is stuck in the stomach or duodenum, electric batteries with a diameter of over $20 \mathrm{~mm}$ are swallowed and have not been excreted within 24 hours, magnets, foreign bodies over 5-6 cm in length and diameter of above $20-25 \mathrm{~mm}$, as well as foreign bodies remaining in the stomach for longer than 3-4 weeks. Particularly predisposed places to wedge the object are natural strictures of the digestive tract, including the duodenal, upper and lower esophageal sphincter, esophagus at the aortic arch, pylorus, ileocecal valve or the anus. ${ }^{26-28}$ The practitioner should also be aware of the possibility of a patient swallowing a drug package. In such a case, they cannot be removed endoscopically due wykonanie bronchoskopii, endoskopii lub tomografii komputerowej..$^{2,21-24}$ Ujemny wynik badania radiologicznego nigdy nie wyklucza obecności ciała obcego w drogach oddechowych lub przewodzie pokarmowym. W związku z tym przy obecności objawów zawsze niezbędna jest dalsza diagnostyka. W przypadku aspiracji kliniczna manifestacja obejmuje występowanie ostrej asfiksji, przewlekłego kaszlu, dławienia się, powtarzających się infekcji górnych dróg oddechowych, krwioplucia oraz zapalenia płuc. Objawy kliniczne w takich sytuacjach mogą imitować te spotykane w przypadku astmy oskrzelowej. ${ }^{9,25}$ Należy pamiętać, że część chorych jest asymptomatyczna i wówczas główną rolę odgrywa diagnostyka radiologiczna i endoskopowa. Do objawów radiologicznych aspiracji zalicza się widoczne, kontrastujące, heterogenne ciało obce, rozedmę, niedodmę lub odmę śródpiersiową. W badaniu endoskopowym można zaobserwować tkankę ziarninową, sekrecję ropy, obrzęk i stwardnienie drzewa oskrzelowego oraz krwawienie. ${ }^{26,27}$

Postępowanie doraźne i leczenie specjalistyczne

Po przeprowadzonym postępowaniu diagnostycznym, w 15-20\% przypadków połknięcia ciała obcego niezbędna jest interwencja w postaci usunięcia endoskopowego lub chirurgicznego (ryc. 3). Wśród grupy osób, których może dotyczyć ten problem dominują dzieci $\mathrm{w}$ wieku od 6 m.ż. do 6 r.ż. oraz osoby w wieku podeszłym. ${ }^{8}$ Wskazaniami do podjęcia interwencji w trybie pilnym są sytuacje, gdy ciało obce zaklinuje się w przełyku, zablokowane kęsy pokarmowe powodują całkowitą dysfagię, połknięte zostaną baterie elektryczne niosące ryzyko perforacji lub poparzenia na tle chemicznym wywołane zawartością baterii, a także ostro zakończone, zwłaszcza obustronnie, połknięte ciała obce. Zabieg w trybie planowym należy rozważyć w następujących sytuacjach: połknięte ciało obce ostro zakończone jest zaklinowane w żołądku lub dwunastnicy, 


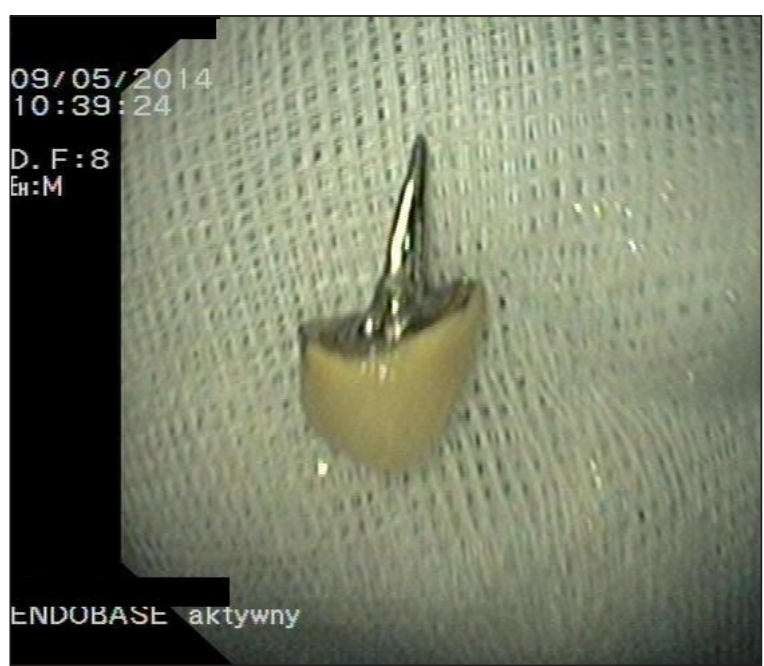

Fig. 3 The removed prosthetic restoration.

Ryc. 3. Ewakuowane uzupetnienie protetyczne u tego samego pacjenta.

to the risk of fatal poisoning, should such a capsule perforate. ${ }^{29}$

In order to carry out the described endoscopic procedures, the surgeon may use methods that can be used in any foreign body removal procedure, such as three-arm pliers, alligator jaws, a rotary gripper, a Dormia basket, a gripper for removing balloons to treat obesity, external tubes (overtube), latex protective caps, polypectomic tweezers, "jumbo" forceps and Roth Net type mesh. ${ }^{26,27}$ The treatment of a patient who has been diagnosed with a foreign body aspiration involves bronchoscopy with a rigid device, which is recommended due to the simultaneous possibility of removing pathological granulation tissue, extracting secretion from the respiratory tract and performing haemostasis. Bronchofiberoscopy is recommended in the previously described diagnostic process, so the techniques performed with a rigid bronchoscope and a bronchofiberoscope are complementary to each other. ${ }^{26,27}$

It is also necessary to keep proper and reliable medical documentation. In the case of połknięte zostają baterie elektryczne o średnicy powyżej $20 \mathrm{~mm}$, jeżeli nie zostały wydalone w ciągu 24h, magnesy, ciała obce o długości powyżej 5-6 cm i średnicy powyżej 20-25 $\mathrm{mm}$, a także ciała obce pozostające w żołądku powyżej 3-4 tygodni. Szczególnie predysponowanymi miejscami do zaklinowania przedmiotu są naturalne zwężenia drogi pokarmowej, w tym pętla dwunastnicy, górny i dolny zwieracz przełyku, przełyk w okolicy łuku aorty, odźwiernik, zastawka krętniczo-kątnicza, czy odbyt. ${ }^{26-28}$ Lekarz praktyk powinien również mieć świadomość możliwości celowego połknięcia przez pacjenta pakietu z narkotykami. W takim wypadku nie można ich usuwać endoskopowo ze względu na ryzyko śmiertelnego zatrucia w przypadku perforacji torebki. W takiej sytuacji zawsze usuwa się je operacyjnie. ${ }^{29}$

W celu przeprowadzenia opisywanych czynności endoskopowych, chirurg może zastosować metody wykorzystujące narzędzia, które mogą znaleźć zastosowanie $\mathrm{w}$ procedurze usuwania ciała obcego, takie jak szczypce trójramienne, szczypce typu ,szczęka aligatora”, chwytak obrotowy, koszyczek Dormia, chwytak do usuwania balonów służących do leczenia otyłości, tuby zewnętrzne (overtube), kapturki ochronne lateksowe, pętle do polipektomii, kleszczyki typu ,jumbo" oraz siatki typu Roth Net. ${ }^{26,27}$ Postępowanie z pacjentem, u którego rozpoznano aspirację ciała obcego obejmuje bronchoskopię aparatem sztywnym, który jest rekomendowany ze względu na jednoczesną możliwość usuwania patologicznej ziarniny, odsysania wydzieliny z dróg oddechowych oraz wykonania hemostazy. Bronchofiberoskopia zalecana jest w opisywanym wcześniej procesie diagnostycznym, tak więc techniki wykonywane bronchoskopem sztywnym i bronchofiberoskopem są komplementarne względem siebie. ${ }^{26,27}$

Niezbędne jest również prowadzenie odpowiedniej i rzetelnej dokumentacji medycznej. W przypadku roszczenia pacjenta, chroni ona lekarza dentystę przed zarzutem zaniechania i 
a patient's claim, it protects the dentist against the charge of negligence and the consequences of professional liability. Documentation should include the type of procedure and precautions that have been taken, the type of a foreign body and the time when it was swallowed or aspirated, the condition of the patient, the actions that have been taken, and the recommendation that was passed on to the patient after the incident. If a hospital intervention was required, the file should also include report on how the patient was transported and to which medical facility. Discussions with the doctor or medical facility staff should also be noted down, and the dentist should ask for a copy of the documentation kept by the attending physician for the records. If the patient refuses a medical assessment or radiological examination, the potential complications that may occur in the patient should be clarified and noted, and their written refusal for the planned diagnostic and treatment procedures should be obtained. ${ }^{12}$

\section{Prevention}

The basis for preventing the occurrence of the described complications is the mechanical protection of the respiratory and digestive tracts. The most common method in dentistry is the use of a rubber dam that isolates the treatment area (a single tooth or a group of teeth) from the rest of the mouth. This is a procedure particularly recommended in endodontics and conservative dentistry. However, also in the case of the rubber dam positioning procedure, precautions should be taken so that the clamp that holds the sheet of rubber is not displaced in an uncontrolled way. In such a situation, the authors recommend securing the clamp by secure it with the dental floss before placing it in the patient's mouth. ${ }^{12,30}$ Similarly, it is recommended to use such protection whenever possible. An example is the ligature of a prosthetic bridge prior to its control in the mouth, which in addition to the protective function, allows its easier and skutkami wynikającymi z odpowiedzialności zawodowej. Dokumentacja powinna obejmować rodzaj wykonywanej procedury i środki ostrożności, które zostały podjęte, rodzaj ciała obcego i czas, w którym został połknięty lub zaaspirowany, stan pacjenta, działania jakie zostały podjęte, a także zalecenie, które zostały przekazane pacjentowi po incydencie. Jeżeli wymagana była interwencja szpitalna, w karcie należy również uwzględnić w jaki sposób pacjent był transportowany i do jakiej placówki medycznej. Należy zanotować również dalsze rozmowy z lekarzem lub placówką medyczną, a dentysta powinien poprosić o kopię dokumentacji prowadzonej przez lekarza prowadzącego dla swoich zapisów. Jeśli pacjent odmawia oceny medycznej lub zdjęć radiologicznych, należy wyjaśnić i odnotować potencjalne powikłania jakie mogą wystąpić u pacjenta, a także uzyskać jego pisemną odmowę na zaplanowane procedury diagnostyczne i leczenie. ${ }^{12}$

\section{Zapobieganie}

Podstawą w zapobieganiu występowania opisywanych powikłań jest mechaniczne zabezpieczenie dróg oddechowych i pokarmowych. Najbardziej rozpowszechniona metodą w stomatologii jest użycie koferdamu, który odizolowuje pole zabiegowe (pojedynczy ząb, bądź ich grupę) od reszty jamy ustnej. Jest to postępowanie szczególnie polecane $\mathrm{w}$ endodoncji i stomatologii zachowawczej. Jednak również w przypadku procedury zakładania koferdamu należy zachować środki ostrożności, aby nie doszło do niekontrolowanego przemieszczenia klamry, utrzymującej gumę koferdamu. Autorzy w takiej sytuacji zalecają zabezpieczenie klamry poprzez jej przywiązanie nitką dentystyczną przed umieszczeniem jej w jamie ustnej pacjenta. ${ }^{12,30}$ Podobnie zaleca się stosowanie takiego zabezpieczenia w każdym przypadku, gdy jest to możliwe. Przykład stanowi ligaturowanie mostu protetycznego przed jego kontrolą w jamie ustnej, co oprócz 
atraumatic removal from the abutments. ${ }^{12}$

The gauze pack plays a similar role to a rubber dam, especially recommended during general anesthesia procedures. Placed in the oral cavity, it is an excellent mechanical blockade that prevents the movement of solid objects - tools, materials, fragments of tissues as well as fluids, such as saliva or coolant to the airways. ${ }^{24}$

Unfortunately, in many situations, the use of these isolations is impossible. In such cases, the operator should take special care with any moveable element in the mouth. When taking impressions, attention should be paid to the proper consistency of the mass and the position of the patient. According to reports in the literature, complications occur if density of the masses is too low and the patient is in the reclining position. In addition, the authors of the quoted papers suggest greater safety related to the use of individual trays with a designed system of excess mass drainage. ${ }^{31,32}$ In the case of procedures with the use of high-speed tools used with water cooling, it is obligatory to use a suction that immediately evacuates any debris from the treatment area, which in the englishlanguage literature is described as "a washed field technique". 32

In selected clinical situations, in patients particularly predisposed to the occurrence of injuries to the facial part of the skull (e.g. patients with epilepsy), a procedure to prevent accidental ingestion or aspiration of prosthetic restorations and fragments of the patient's own tissues should be implemented. Patients suffering from epilepsy should use acrylic plate strengthening nets, which prevent a separation of its fragment from the rest of the restoration and, if possible, use fixed restorations or cast dentures. Literature reports indicate that this type of trauma in epileptics is not uncommon, and so epilepsy should be routinely considered as an indication for the modification of the design of removable dentures. ${ }^{15,16}$ Another funkcji zabezpieczającej, pozwala na jego łatwiejsze $\mathrm{i}$ atraumatyczne usunięcie $\mathrm{z}$ filarów. ${ }^{12}$

Podobną rolę do koferdamu spełnia seton gazowy, szczególnie polecany podczas zabiegów w znieczuleniu ogólnym. Umieszczony w jamie ustnej stanowi mechaniczną blokadę, zabezpieczającą przed przemieszczeniem się ciał stałych - narzędzi, materiałów i fragmentów tkanek oraz płynów, takich jak ślina czy chłodziwo - do dróg oddechowych. ${ }^{24}$

W wielu sytuacjach zastosowanie opisanych barier jest niemożliwe. Wówczas operator powinien zachować szczególną ostrożność z każdym potencjalnie ruchomym materiałem znajdującym się w jamie ustnej. W przypadku pobierania wycisków należy zwrócić uwagę na właściwą konsystencję masy oraz pozycję pacjenta. Zgodnie $\mathrm{z}$ doniesieniami w piśmiennictwie, do powikłań dochodzi w przypadku zbyt rzadkich mas oraz pozycji leżącej pacjenta. Ponadto autorzy cytowanych prac sugerują większe bezpieczeństwo związane z zastosowaniem łyżek indywidualnych z zaprojektowanym systemem drenażu nadmiaru masy. ${ }^{31,32} \mathrm{~W}$ przypadku procedur z użyciem narzędzi szybkoobrotowych stosowanych wraz z chłodzeniem wodnym należy obligatoryjnie stosować ssak, którego celem jest natychmiastowe oczyszczanie pola zabiegowego, co w piśmiennictwie anglojęzycznym opisywane jest jako washed field technique. ${ }^{32}$

W wybranych sytuacjach klinicznych, u pacjentów szczególnie predysponowanych do wystąpienia urazów w obrębie części twarzowej czaszki (np. pacjenci z epilepsją), należy wdrożyć postępowanie, którego celem jest zabezpieczenie przed przypadkowym połknięciem lub aspiracją uzupełnień protetycznych i fragmentów własnych tkanek pacjenta. U pacjentów cierpiących na padaczkę należy stosować wzmocnienie lane lub siatki wzmacniające płytę protezy akrylowej, które zabezpieczają przed oderwaniem jej fragmentu od całości, a jeśli tylko jest to możliwe zastosować 
group constitutes patients who regularly play sports where mechanical craniofacial injuries are possible. The individually designed protective splint provides excellent protection against damage to the teeth, alveolar bone of the jaws and soft tissues of the mouth. ${ }^{33}$

\section{Summary}

Each, even the simplest medical procedure, carries a risk of complications. In the case of dental treatment, regardless of the procedure performed, the dentist should account for the possibility of accidental aspiration or ingestion of a tool, material placed in the oral cavity or fragments of patient's own tissues. Risk evaluation is important, taking into account factors related to the patient, such as age, mental state, anatomical structure of the nasopharynx, as well as factors related to procedure - equipment used, the position of the patient in the dental chair and the materials, in particular, their consistency. Preventive actions should be implemented at each stage, and if complications occur, the first aid measures to remove the foreign body. If unsuccessful, the patient's condition should be monitored and methods should be used that go beyond the competence of the dentist, including surgical treatment. However, it is necessary to emphasize the important role of preventive factors, which should be an obligatory element of treatment, such as the use of a rubber dam in the case of endodontic procedures or securing small elements before their placement in the mouth. Such procedures significantly reduce the risk and make the procedure predictable and safe. uzupełnienia stałe lub protezę szkieletową. Jak wynika z piśmiennictwa, tego typu urazy u epileptyków nie są rzadkością, co powinno skłonić do rutynowego uwzględniania tego schorzenia jako wskazania do modyfikacji budowy protez ruchomych. ${ }^{15,16}$ Inną grupę stanowią pacjenci, którzy regularnie uprawiają sport. Indywidualnie zaprojektowana szyna ochronna stanowi doskonałe zabezpieczenie przed uszkodzeniem zębów, kości wyrostka zębodołowego oraz tkanek miękkich jamy ustnej. ${ }^{33}$

\section{Podsumowanie}

Każda, nawet najprostsza procedura medyczna, niesie ze sobą ryzyko wystąpienia powikłań. W przypadku leczenia stomatologicznego, lekarz powinien liczyć się z możliwością wystąpienia przypadkowej aspiracji lub połknięcia przez pacjenta narzędzia, materiału wprowadzanego do jamy ustnej, czy fragmentów własnych tkanek. Istotna jest ewaluacja ryzyka, uwzględniająca czynniki zależne od pacjenta, jak wiek, stan psychiczny, czy budowę anatomiczną nosogardła oraz czynniki związane z zabiegiem - używane narzędzia, pozycję pacjenta na fotelu dentystycznym oraz stosowane materiały. Na każdym etapie należy wdrażać działania zapobiegawcze, a w razie wystąpienia omawianych komplikacji - pierwszą pomoc, której celem jest usunięcie ciała obcego. W przypadku niepowodzenia należy monitorować stan pacjenta i sięgać po metody wykraczające poza kompetencje lekarza dentysty. Jednak trzeba podkreślić istotną rolę czynników zapobiegawczych, które powinny być obowiązkowym elementem leczenia, jak stosowanie koferdamu, czy przywiązywanie drobnych elementów wprowadzanych do jamy ustnej. Takie postępowania w znaczący sposób redukuje ryzyko i sprawia, że przeprowadzany zabieg staje się przewidywalny i bezpieczny. 


\section{References / Piśmiennictwo}

1. Wochna K, Jurczyk A, Smędra-Kaźmirska A, Berent J: Bezobjawowa aspiracja wiertła stomatologicznego do dolnych dróg oddechowych - opis przypadku. Archiwum Medycyny Sądowej i Kryminologii 2014; 63, 2: 114-117.

2. Bains R, Loomba K, Sinha S, Bains VK: Accidental swallowing of endodontic instrument: Could be a medical emergency. Eur J Gen Dent 2014; 3: 202-204.

3. Jain A, Baliga SD: Accidental Implant Screwdriver Ingestion: A Rare Complication during Implant Placement. J Dent (Tehran) 2014; 11: 711-714.

4. Kurkciyan I, Frossard M, Kettenbach J, Meron G, Sterz F, Roggla M, Laggner AN: Conservative management of foreign bodies in the gastrointestinal tract. Z Gastroenterol 1996; 34, 3: 173-177.

5. Hisanaga R, Hagita K, Nojima K, Katakura A, Morinaga K, Ichinohe T, Konomi R, Takahashi T, Takano N, Inoue T: Survey of Accidental Ingestion and Aspiration at Tokyo Dental College Chiba Hospital. Bull Tokyo Dent Coll 2010; 51, 2: 95-101.

6. Milton TM, Hearing $S D$, Ireland $A J$ : Ingested foreign bodies associated with orthodontic treatment: report of three cases and review of ingestion/aspiration incident management. $\mathrm{Br}$ Dent J 2001; 190: 592-596.

7. Cameron SM, Whitlock WL, Tabor MS: Foreign body aspiration in dentistry: a review. J Am Dent Assoc 1996; 127: 1224-1229.

8. Tiwana KK, Morton T, Tiwana PS: Aspiration and ingestion in dental practice: a 10-year institutional review. J Am Dent Assoc 2004; 135: 1287-1291.

9. Susini G, Pommel L, Camps J: Accidental ingestion and aspiration of root canal instruments and other dental foreign bodies in a French population. Inter Endodont J 2007; 40: 585-589.

10. Yadav RK, Yadav HK, Chandra A, Yadav S,
Verma P, Shakya VK: Accidental aspiration/ ingestion of foreign bodies in dentistry: A clinical and legal perspective. Natl J Maxillofac Surg 2015; 6, 2: 144-151.

11. Tsitrou E, Germanidis G, Boutsiouki C, Koulaouzidou E, Koliniotou-Koumpia E: Accidental ingestion of an air-water syringe tip during routine dental treatment: a case report. J Oral Sci 2014; 56: 235-238.

12. Hill EE, Rubel B: A practical review of prevention and management of ingested/ aspirated dental items. General Dentistry 2008; 56, 7: 691-694.

13. Wróbel-Bednarz $K$, Basiaga $M$, Walke $W$, Mierzwińska-Nastalska E: Analiza wytrzymałościowa układu ząb-cement-kompozytowy wkład koronowo-korzeniowy wzmacniany włóknem szklanym. Dent Med Probl 2015; 52, 1: 62-70.

14. Zicari F, Coutinho E, Scotti R, Van Meerbeek $B$, Naert I: Mechanical properties and micromorphology of fiber posts. Dent Mater 2013; 29: 45-52.

15. Gawlak D, Łuniewska J, Stojak W, Hovhannisyan A, Stróżyńska A, MańkaMalara K, Adamiec M, Rysz A: The prevalence of orodental trauma during epileptic seizures in terms of dental treatment - Survey study. Neurol Neurochir Pol 2017; 51, 5: 361-365.

16. Borsuk-Nastaj B, Tomera K, Wróbel K, Watek A, Jonasz M: Rehabilitacja protetyczna pacjentów chorych na padaczkę - opis przypadku. Nowa Stomatologia 2008; 13, 4: 141-146.

17. Pavlidis T, Marakis G, TriantafyllouA, Psarras K, T Kontoulis, Sakantamis A: Management Of Ingested Foreign Bodies: How Justifiable Is A Waiting Policy? The Internet Journal of Surgery 2006; 9, 1.

18. Loh KS, Tan LK, Smith JD, Yeoh KH, Dong $F$ : Complications of foreign bodies in the esophagus. Otolaryngol Head Neck Surg 2000; 123, 5: 613-616. 
19. Silva RF, Martins EC, Prado FB, Júnior $J R$, Júnior ED: Endoscopic removal of an endodontic file accidentally swallowed: clinical and legal approaches. Aust Endod J 2011; 37: 76-78.

20. Louie MC, Bradin S: Foreign Body Ingestion and Aspiration. Pediatrics in Review Aug 2009; 30, 8: 295-301.

21. Grossman LI: Prevention in endodontic practice. J Am Dent Assoc 1971; 82: 395-396.

22. Knowles JE: Inhalation of dental plates - a hazard of radiolucent materials. J Laryngol Otol 1991; 105: 681-682.

23. Ong TK, Lancer JM, Brook IM: Inhalation of a denture fragment complicating facial trauma. Br J Oral Maxillofac Surg 1988; 26, 6: 511-513.

24. Almuthhin $M$, Aljahdali A, Alzahrani $M$, Alhusain B, Algamdi $Y$ : Accidental ingestion of the endodontic instrument: a case report. European Journal of Medical Case Reports 2017; 1, 3: 148-151.

25. Brady PG: Esophageal foreign bodies. Gastroenterol Clin North Am 1991; 20, 4: 691-701.

26.Dąrowski A, Antczak A, Myśliwiec $M$, Pruszczyk $P$ : Wielka interna Gastroenterologia, Medical Tribune Polska, Warszawa, 2010, część 1.

27. Classen M, Tytgat G, Lightdale C: Endoskopia układu pokarmowego. MMedia, Warszawa, 2012.

28. Singh B, Nijhawan S, Narayan KS, Kumar A: Endoscopic management of ingested foreign bodies and food impaction in esophagus. $\mathrm{J}$ Dig Endosc 2015; 6: 96-100.

29. Sinner WM: The gastrointestinal tract as a vehicle for drug smuggling. Gastrointestinal Radiology 1981; 6, 1: 319-323.

30. Saraf HP, Nikhade PP, Chandak MG: Accidental Ingestion of Endodontic File: A Case Report. Case Reports in Dentistry 2012; e278134.

31. Kimberly DR: Unrecognized aspiration of a mandibular incisor. J Oral Maxillofac Surg 2001; 59: 350-352.

32. Fields RT, Schow SR: Aspiration and ingestion of foreign bodies in oral and maxillofacial surgery: A review of the literature and report of five cases. J Oral Maxillofac Surg 1998; 56: 1091-1098.

33. Gawlak D, Łojszczyk R: Materiały i metody stosowane w wykonawstwie ochraniaczy jamy ustnej użytkowanych podczas uprawiania różnych dyscyplin sportowych. Stomatologia Współczesna 2010; 17, 1: 8-15.

Zaakceptowano do druku: 30.05.2019 r. Adres autorów: 02-006 Warszawa, ul. Nowogrodzka 59. (C) Zarząd Główny PTS 2019. 